\title{
ADAM BŁACHNIO
}

Uniwersytet Kardynała Stefana Wyszyńskiego

\section{DOKUMENTACJA MEDYCZNA W POSTĘPOWANIU KARNYM}

\section{WPRowadZenie}

Problematyka dokumentacji medycznej, z uwagi na jej złożony charakter, a jednocześnie niezwykle istotną rolę, jaką pełni w procesie leczenia pacjenta, stanowi kwestię doniosłą, w szczególności z punktu widzenia prawa karnego. Podstawową funkcją, jaką należy jej przypisać, jest funkcja informacyjna, albowiem zawiera ona nie tylko podstawowe dane pozwalające na identyfikację pacjenta, jego dane personalne i teleadresowe, ale także szczegółowe opisy schorzeń dolegających pacjentowi, zleconych badań, przepisanych przez lekarza środków farmakologicznych czy też informacje o charakterze administracyjnym, pozwalające na ustalenie danych osoby prowadzącej konkretnego pacjenta, przebiegu pobytu w placówce służby zdrowia, a nawet adnotacje o pobraniu ze zwłok komórek, tkanek lub narządów. Z tego też względu dokumentacja medyczna stanowi cenne źródło dowodowe w postępowaniu karnym. To właśnie dzięki tej dokumentacji prowadzący postępowanie może ustalić podstawowe fakty dotyczące leczenia pacjenta, a także na podstawie wpisów w niej poczynionych podjąć próbę rekonstrukcji zdarzenia, w szczególności w oparciu o opinie biegłych, czy sposób leczenia konkretnego pacjenta był prawidłowy, czy też doszło do naruszenia zasad 
wiedzy i sztuki medycznej w wyniku których doznał on określonego uszczerbku na zdrowiu bądź na taki uszczerbek został bezpośrednio narażony ${ }^{1}$. Z kolei sporządzenie opinii w oparciu o dokumentację niepełną czy prowadzoną w sposób nierzetelny może skutkować obarczeniem takiej opinii błędem czy innego rodzaju wadami wpływającymi na jej ocenę merytoryczną. Jak słusznie podnosi się w literaturze, dokumentacja medyczna często określana jest mianem „niemego świadka”, a więc osoby posiadającej niewerbalną (aczkolwiek weryfikowalną) wiedzę dotyczącą przebiegu leczenia pacjenta ${ }^{2}$. Ponadto, jak słusznie wskazują G. Teresiński oraz R. Mądro, dzięki zasadom prowadzenia tego rodzaju zbioru danych, takim jak zasada dublowania informacji, zasada chronologicznego dokonywania wpisów czy też prowadzenie rejestrów o charakterze indywidualnym oraz zbiorczym, może ona podlegać zweryfikowaniu, nawet w przypadku dokonywania niezgodnych z prawem zmian w jednym ze zbiorów. W takim przypadku następuje bowiem najczęściej podrobienie bądź przerobienie tylko jednego wpisu,

1 Oczywiście dokonałem tutaj pewnego uproszczenia w zakresie pojęcia błędu medycznego. Jak wskazuje się w literaturze, pojęcie to jest wieloznaczne, zaś jego definicja należy do spornych - por. M. Wolıńska, Odpowiedzialność karna lekarza za błąd w sztuce lekarskiej, «Prokuratura i Prawo» 5/2013, s. 19-23; S. Rutкowski, Wybrane zagadnienia z zakresu odpowiedzialności karnej lekarza, "Prokuratura i Prawo» 9/1999, s. 71 i n.; A. FiutAk, Prawo w medycynie, Warszawa 2011, s. 77-78. Wydaje mi się jednak, że najbardziej trafna jest definicja błędu medycznego w ujęciu zaproponowanym przez A. Liszewską, która przez błąd w sztuce medycznej rozumie „naruszenie przez lekarza (świadomego tego, że podejmuje czynność medyczną) obowiązujących go w konkretnym przypadku wypadku, wypracowanych na gruncie nauki i praktyki reguł postępowania zawodowego wobec dóbr prawnych w postaci życia i zdrowia człowieka, które na gruncie prawa stanowi podstawę do stwierdzenia naruszenia reguł ostrożności” - por. A. LiszewskA, Odpowiedzialność karna lekarza za błąd w sztuce lekarskiej, Zakamycze 1998 s. 28. Tradycyjnie przyjmuje się, że błąd lekarski może przyjąć postać błędu diagnostycznego, terapeutycznego, technicznego oraz organizacyjnego - szerzej ibidem, s. 153-199.

2 Por. K. Kordel, Prowadzenie dokumentacji medycznej-implikacje dowodowe, «Prawo i Medycyna» 3/2006 s. 100 i n..; tak też P. Prochopień, [w:], Dokumentacja medyczna, red. T. Banaś, T. Filarski, M. Mikos, P. Prochopień, Warszawa ABC 2012 - System Informacji Prawnej Lex (Lex Omega). 
a nie wszystkich odnoszących się do konkretnego stanu faktycznego ${ }^{3}$. Dokumentacja medyczna, z prawnokarnego punktu widzenia ma jednak szersze znaczenie. Może ona stanowić odrębny przedmiot postępowania, w szczególności dotyczącego podrabiania dokumentów ${ }^{4}$ czy poświadczania w nich nieprawdy, bądź nawet stanowić jeden $z$ elementów przestępstwa $\mathrm{z}$ art. 286 k.k., jeżeli zawarte w niej informacje służyły wprowadzeniu Narodowego Funduszu Zdrowia w błąd celem uzyskania korzyści majątkowej. Nie podejmując jednak szczegółowego rozważania w tym zakresie, należy odnieść się do samego pojęcia dokumentacji medycznej, a następnie przejść do jej rodzajów, podstaw prawnych prowadzenia, jak również możliwości wykorzystania w postępowaniu karnym.

\section{PojęCie dokumentacji MedyCZnej}

Sformułowanie „dokumentacja medyczna” w obecnie obowiązującym porządku prawnym nie zostało zdefiniowane. Oczywiście pojęcie dokumentu na gruncie kodeksu karnego zostało określone w art. $115 \$ 14$ jako przedmiot lub inny zapisany nośnik informacji, z którym jest związane określone prawo, albo który ze względu na zawartą w nim treść stanowi dowód prawa, stosunku prawnego lub okoliczności mającej znaczenie prawne. Pomimo faktu, iż definicja legalna dokumentu nie zawiera w swoim członie przymiotnika „medyczna”, może ona stanowić cenne źródło informacji również o dokumentacji medycznej ${ }^{5}$. Po pierwsze bowiem, art. $115 \$ 14$ k.k. wskazuje de facto na dwa podstawowe sposoby utrwalenia takich informacji - bądź to jako przedmiot (np. zapisana kartka papieru), bądź też jako zapisany nośnik informacji (najczęściej

\footnotetext{
3 Por. G. Teresiński, R. MĄDro, Rola dokumentacji medycznej w opiniowaniu sądowo-lekarskim, «Prokuratura i Prawo»11/2002 s. 25 i n.

4 Por. przypadki opisane w opracowaniu M. LegIeŃ, Kryminalistyczna ocena wiarygodności dokumentacji medycznej w opiniowaniu sądowo-lekarskim, «Prokuratura i Prawo» 10/1999 s. 109-112.

5 Z leksykalnego punktu widzenia dokumentacja medyczna stanowi pewien szczególny zbiór dokumentów, którego zakres został ograniczony przez dodanie określnika „medyczna”.
} 
w systemie binarnym). ${ }^{6}$ Drugim elementem, stanowiącym warunek sine quo non definicji dokumentu, jest jego merytoryczna zawartość, a więc treść mająca znaczenie prawne (np. pobyt w szpitalu, udzielenie zwolnienia, dokonywanie wpisu o zabiegach etc.) $)^{7}$. Poszukując definicji legalnej, należy jednak zwrócić się w kierunku aktów prawnych, które regulują kwestie związane z prowadzeniem takiej dokumentacji, a w szczególności odwołać się do aktów prawnych dotyczących ochrony zdrowia. Ustawa z dnia 5 grudnia 1996 r. o zawodzie lekarza i lekarza dentysty $^{8}$ nie wprowadza, w żadnej jednostce redakcyjnej, definicji dokumentacji medycznej z uwagi na odrębny przedmiot regulacji, którym są zasady i warunki wykonywania zawodów lekarza i lekarza dentysty. Bezpośrednie odwołanie do powyższego sformułowania możemy jednak odnaleźć w ustawie z 15 kwietnia 2011 r. o działalności leczniczej9. Zgodnie z art. 1, ustawa określa zasady wykonywania działalności leczniczej, zasady funkcjonowania podmiotów wykonujących działalność leczniczą niebędących przedsiębiorcami, zasady prowadzenia rejestru podmiotów wykonujących działalność leczniczą, normy czasu pracy pracowników podmiotów leczniczych, a także zasady sprawowania nadzoru nad wykonywaniem działalności leczniczej oraz podmiotami wykonującymi działalność leczniczą. W art. 2 zawarto słowniczek po-

${ }^{6}$ Jak słusznie zauważa J. Majewski, „dokumentem może być in concreto każdy nośnik informacji zarówno materialny („przedmiot”), jak i niematerialny. Podłoże, na jakim zapisano określoną informację (treść), jest z punktu widzenia art. $115 \$ 14$ obojętne - J. Majewski, [w:] G. Bogdan, Z. ĆwiąKALski, P. KARdas, J. Majewski, J. Raglewski, M. SzewCzyK, W. Wróbel, A. Zoll, Kodeks karny. Część ogólna. Komentarz, I: Komentarz do art. 1-116 k.k., red. A ZoLL, Zakamycze 2004, s. 1462.

7 Jak słusznie stwierdził SN w wyroku z 23 maja 2013 r. (sygn. IV KK 60/13), poświadczenie przez lekarza medycyny w wystawionej recepcie nieprawdy co do osoby mającej korzystać z leku, który podlega refundacji z Narodowego Funduszu Zdrowia, dotyczy okoliczności mającej znaczenie prawne w rozumieniu art. $271 \$ 1$ k.k. Niezależnie od powyższego dokonywane przez lekarzy wpisy w tego rodzaju dokumentacji mają istotne znaczenie prawne nie tylko z punktu widzenia prawa do określonych świadczeń zdrowotnych czy możliwości uzyskania środków farmaceutycznych, ale także z punktu widzenia samego prawa karnego jako dowód okoliczności mającej znaczenie prawne (np. w zakresie odpowiedzialności lekarza za proces leczenia).

8 Tekst jednolity Dz.U. z 2015 r., poz. 464.

$9 \quad$ Dz.U. z 2011 r. Nr 112, poz. 654. 
jęć użytych w ustawie, zgodnie z którym użyte w ustawie określenie „dokumentacja medyczna”, oznacza dokumentację medyczną, o której mowa w przepisach ustawy z dnia 6 listopada 2008 r. o prawach pacjenta i Rzeczniku Praw Pacjenta (Dz. U. z 2012 r. poz. 159). Tym samym jest to definicja odsyłająca do innego aktu prawnego. Przepisy tej ustawy posługują się sformułowaniem „dokumentacja medyczna” co najmniej w kilku jednostkach redakcyjnych (m.in. w art. 1, 23 25, 26 ust. 1 i 4, 27, 29 ust. 1), jednakże nie definiują tego pojęcia. W rozdziale 7 ustawy, zatytułowanym Prawo pacjenta, dla dokumentacji medycznej wskazano podstawowe elementy, które taka dokumentacja musi zawierać (imię i nazwisko pacjenta, datę urodzenia, oznaczenie płci, adres miejsca zamieszkania, numer PESEL, jeżeli został nadany, w przypadku noworodka - numer PESEL matki, a w przypadku osób, które nie mają nadanego numeru PESEL - rodzaj i numer dokumentu potwierdzającego tożsamość, w przypadku, gdy pacjentem jest osoba małoletnia, całkowicie ubezwłasnowolniona lub niezdolna do świadomego wyrażenia zgody - nazwisko i imię (imiona) przedstawiciela ustawowego oraz adres jego miejsca zamieszkania, oznaczenie podmiotu udzielającego świadczeń zdrowotnych ze wskazaniem komórki organizacyjnej, w której udzielono świadczeń zdrowotnych, opis stanu zdrowia pacjenta lub udzielonych mu świadczeń zdrowotnych oraz datę sporządzenia). Wymagania te stanowią pewne absolutne minimum wprowadzone przez ustawodawcę, dotyczące elementów składowych. Z kolei w art. 30 ust. 1 ustawy zawarto delegację ustawową dla Ministra Zdrowia, który w drodze rozporządzenia, winien określić rodzaj i zakres dokumentacji medycznej, sposób jej przetwarzania oraz wzory określonych rodzajów dokumentacji medycznej, w szczególności wzór książeczki zdrowia dziecka, uwzględniając rodzaje podmiotów udzielających świadczeń zdrowotnych, a także konieczność zapewnienia realizacji prawa dostępu do dokumentacji medycznej, rzetelnego jej prowadzenia, ochrony danych i informacji dotyczących stanu zdrowia pacjenta oraz jednolitych wzorów dokumentacji medycznej mającej istotne znaczenie dla szybkiego i skutecznego udzielania świadczeń zdrowotnych. Delegacja ustawowa została zrealizowana poprzez wydanie w dniu 21 grudnia 2010 r. rozporządzenia Ministra Zdrowia w sprawie rodzajów i zakresu dokumentacji 
medycznej oraz sposobu jej przetwarzania ${ }^{10}$. Akt ten jednak również nie zawiera definicji legalnej dokumentacji medycznej, wprowadzając jedynie jej podziały oraz, w sposób szczegółowy, wskazując, jakie są jej elementy składowe. Powstaje zatem pytanie, czy żaden akt prawny nie wprowadzał definicji legalnej dokumentacji medycznej. Analiza obowiązującego stanu prawnego, jak wskazano powyżej, nie dostarcza nam odpowiedzi na powyższe pytanie. Definicję taką zawierała nieobowiązująca obecnie ustawa z dnia 30 sierpnia 1991 r. o zakładach opieki zdrowotnej ${ }^{11}$, która w art. 18d ust. 1 pkt 5 definiowała dokumentację medyczną jako „określone w ustawie oraz przepisach odrębnych dane i informacje medyczne odnoszące się do stanu zdrowia pacjenta lub udzielonych mu w zakładzie opieki zdrowotnej świadczeń zdrowotnych".

Niewątpliwie godząc się z twierdzeniem, że każda definicja wprowadza pewien element zagrożenia, na podstawie powyższych aktów prawnych, w szczególności przepisów rozporządzenia Ministra Finansów z 21 grudnia 2010 r. oraz ustawy o prawach pacjenta i Rzeczniku Praw Pacjenta, można wskazać pewne elementy składowe, które na taką dokumentacją muszą się składać. Po pierwsze, dokumentacja taka może być prowadzona zarówno w formie papierowej, jak również elektronicznej - na co expressis verbis wskazuje $\$ 1 \mathrm{w} / \mathrm{w}$ rozporządzenia. Po drugie, musi ona zawierać dane pozwalające na zidentyfikowanie konkretnego pacjenta, który podlega czynnościom leczniczym. Po trzecie, poza informacjami o charakterze identyfikacyjnym, zawiera ona przede wszystkim treści odnoszące się do stanu zdrowia pacjenta, w szczególności dotyczące czynności leczniczych, przepisywanych leków, a także inne informacje związane ze stanem zdrowia pacjenta i udzielanych mu świadczeń zdrowotnych. Po czwarte, dokumentacja taka musi być sporządzana dla celów leczniczych i przez uprawnionego do tego pracownika służby zdrowia. Po piąte wreszcie, musi ona spełniać wymagania formalne określone $\mathrm{w}$ w/w rozporządzeniu Ministra Zdrowia ${ }^{12}$.

\footnotetext{
10 Tekst jednolity Dz.U. z 2014 r., poz. 177.

11 Dz.U. nr. 91 poz. 408 ze zm.

12 Por. też J. Bielasińki, Dokumentacja medyczna jawna dla pacjenta, «Jurysta» 11/2001, s. 19. Własną definicję dokumentacji medycznej zaproponował R. Kubiak, który wskazuje, że „dokumentacja medyczna jest zbiorem danych opisujących stan
} 
Dokumentacja spełniająca powyższe kryteria niewątpliwie mieści się również w legalnej definicji dokumentu z art. $115 \$ 14$ k.k.

\section{Podmiot upRaWNiony do PROWADZENia DOKUMENTACJi MEDYCZNEJ}

Zgodnie z art. 24 ust. 1 w zw. $z$ art. 23 ust. 1 ustawy o prawach pacjenta i Rzeczniku Praw Pacjenta podmiot udzielający świadczeń zdrowotnych jest obowiązany prowadzić, przechowywać i udostępniać dokumentację medyczną oraz zapewnić ochronę danych zawartych w tej dokumentacji w celu realizacji praw pacjenta do dostępu do dokumentacji medycznej dotyczącej jego stanu zdrowia oraz udzielonych świadczeń zdrowotnych ${ }^{13}$. Zgodnie $\mathrm{z}$ art. 2 pkt $5 \mathrm{w}$ zw. z art. 4 i 5 ustawy z dnia 15 kwietnia 2011 r. o działalności leczniczej ${ }^{14}$ podmiotem udzielającym świadczeń zdrowotnych jest podmiot wykonujący działalność leczniczą w rozumieniu ustawy o działalności leczniczej (a więc podmiot leczniczy i praktyka zawodowa). Jako podmioty lecznicze ustawa wskazuje m.in. samodzielne publiczne zakłady opieki zdrowotnej, instytuty badawcze, przedsiębiorców, jednostki budżetowe posiadające w strukturze organizacyjnej ambulatorium, ambulatorium $\mathrm{z}$ izbą chorych lub lekarza oraz inne jednostki - w zakresie, w jakim wykonują działalność leczniczą (art. 4 i 5 ustawy). Każdy podmiot,który zamierza wykonywać działalność leczniczą jako podmiot leczniczy, jest zobowiązany złożyć wniosek o wpis do rejestru podmiotów wykonujących działalność leczniczą zawierających m.in. imię i nazwisko, nazwę albo firmę, adres siedziby

zdrowia pacjenta oraz zakres udzielanych mu świadczeń" - R. KubIAK, Prawo medyczne, Warszawa 2010, s. 245-246. Ujęcie takie nie zawiera jednak elementów związanych z podmiotem uprawnionym do prowadzenia dokumentacji medycznej, jak również nie wskazuje formy jej prowadzenia.

13 Jak słusznie zauważa A. Fiutak, w ramach tego podmiotu dokumentacja medyczna jest sporządzona przez lekarza zajmującego się pacjentem, co wynika z art. 41 ustawy o zawodzie lekarza i lekarza dentysty - por. A. FiUtAK, [w:] U. Drozdowska, P. Dzienis, A. Górski, E. Rozwadowska, W. ZaŁuski, A. Fiutak, Leksykon prawa medycznego, red. A. Górski, Warszawa 2012, s. 19.

14 Dz. U. 2011 r. Nr 112, poz. 654. 
albo miejsca zamieszkania, adres miejsca udzielania świadczeń zdrowotnych, rodzaj działalności leczniczej oraz zakres udzielanych świadczeń zdrowotnych (art. 100 ustawy). Przepisy ustawy przewidują odrębne wymogi dla lekarza oraz pielęgniarki, którzy zamierzają wykonywać zawód w ramach działalności leczniczej. Wniosek o wpis należy złożyć do organów właściwych do prowadzenia rejestru, tj. wojewody właściwego dla siedziby albo miejsca zamieszkania podmiotu leczniczego - w odniesieniu do pomiotów leczniczych, okręgowa rada lekarska właściwa dla miejsca wykonywania praktyki zawodowej lekarza, okręgowa rada pielęgniarek i położnych właściwa dla miejsca wykonywania praktyki zawodowej przez pielęgniarkę. Rejestr prowadzony jest w systemie teleinformatycznym Zgodnie z art. 107 ust. 1 ustawy, podmiot wykonujący działalność leczniczą, wpisany do rejestru, zobowiązany jest zgłaszać organowi prowadzącemu rejestr wszelkie zmiany danych objętych rejestrem w terminie 14 dni od dnia ich powstania - pod rygorem nałożenia kary pieniężnej w wysokości do dziesięciokrotnej wysokości minimalnego wynagrodzenia za pracę. Istotne regulacje dotyczą sprawowania nadzoru nad podmiotami leczniczymi, albowiem, z jednej strony, nadzór ten jest sprawowany przez organ prowadzący rejestr w zakresie zgodności wykonywanej działalności z przepisami określającymi warunki wykonywania działalności leczniczej (art. 111 ust. 1). Z drugiej zaś strony nadzór merytoryczny sprawuje minister właściwy do spraw zdrowia, który ma prawo przeprowadzenia kontroli podmiotów leczniczych pod względem zgodności z prawem oraz medycznym. Ponadto nadzór nad podmiotem leczniczym niebędącym przedsiębiorcą sprawuje podmiot tworzący.

Powyższe regulacje dotyczące podmiotów, które są uprawnione do prowadzenia działalności leczniczej, a tym samym zobowiązane do prowadzenia dokumentacji medycznej, z punktu widzenia prawa karnego mają istotne znaczenie z uwagi na możliwości dowodowe, a także w zakresie inicjowania czynności kontrolnych. W pierwszej kolejności sięgając do w/w rejestru, można ustalić nie tylko podstawowe dane dotyczące konkretnego podmiotu czy osób go reprezentujących, ale także uzyskać informacje dotyczące np. zakresu praktyki, którą w ramach działalności prowadzi. Ponadto, w przypadku stwierdzenia nieprawidłowości, brak 
jest przeszkód, aby prokurator, w trybie art. 19 k.p.k. wystąpił z sygnalizacją nieprawidłowości do właściwego organu sprawującego nadzór nad tym podmiotem.

\section{RodZAJE DOKUMENTACJI MEDYCZNEJ ORAZ JEJ ZAWARTOŚĆ}

Zgodnie z art. 25 ustawy z dnia 06 listopada 2008 r. o prawach pacjenta i Rzeczniku Praw Pacjenta dokumentacja medyczna musi zawierać co najmniej oznaczenie pacjenta, pozwalające na ustalenie jego tożsamości (imię i nazwisko, datę urodzenia, oznaczenie płci, adres miejsca zamieszkania, numer PESEL, dane przedstawicieli ustawowych - w przypadku osoby ubezwłasnowolnionej), oznaczenie podmiotu udzielającego świadczeń zdrowotnych ze wskazaniem komórki organizacyjnej, w której udzielono świadczeń zdrowotnych, opis stanu zdrowia pacjenta lub udzielonych mu świadczeń zdrowotnych, datę sporządzenia. Powyższa regulacja stanowi pewne minimum wymagań stawianych przez ustawodawcę. W sposób kompleksowy kwestia ta została uregulowana w rozporządzeniu Ministra Zdrowia z dnia 21 grudnia $2010 \mathrm{r}$. w sprawie rodzaju i zakresu dokumentacji medycznej oraz sposobu jej przetwarzania, które w sposób bardzo dokładny wskazuje rodzaje dokumentacji medycznej, jaka jest prowadzona w podmiotach udzielających świadczeń zdrowotnych. Oczywiście, sam zakres jej prowadzenia może być różny, w zależności od specyfikacji świadczeń, jakie dany podmiot oferuje pacjentom ${ }^{15}$. Jednakże rozporządzenie wskazuje rodzaje dokumentacji medycznej, jak również informacje, które są w niej zawierane. $\mathrm{Z}$ praktycznego punktu widzenia omawiane zagadnienie jest bardzo istotne, albowiem w zależności od rodzaju dokumentacji, po jaki się zwrócimy, może ona nie obrazować nam w sposób dokładny przebiegu zdarzenia. Wyobraźmy sobie sytuację, w której pacjent po wykonanym zabiegu chirurgicznym umiera na sali pooperacyjnej. $Z$ punktu widzenia

15 Oczywistym jest, że przychodnia rejonowa nie będzie przykładowo prowadziła dokumentacji zbiorczej dotyczącej bloku operacyjnego czy księgi noworodków, albowiem nie świadczy ona tego rodzaju usług. 
postępowania karnego i odpowiedzialności karnej, będzie istotne nie tylko to, czy zabieg był przeprowadzony w sposób zgodny z regułami sztuki i wiedzy medycznej, ale także to, czy opieka na sali pooperacyjnej była prawidłowa, czy pacjent był stale monitorowany czy też nie, czy nie został zbyt szybko przeniesiony na salę ogólną (gdzie nadzór nad pacjentem jest mniejszy). W omawianym przypadku, zwracając się wyłącznie po dokumentację dotyczącą konkretnego pacjenta, nie uzyskamy odpowiedzi na powyższe pytania, a jedynie na kwestie związane z przeprowadzonym zabiegiem. Zwracając się jednak po dokumentację zbiorową, możemy ustalić całą „drogę” pacjenta w placówce służby zdrowia (w tym także np. odmowę udzielenia świadczenia).

Zgodnie $\mathrm{z} \$ 2$ rozporządzenia dokumentację stanowi:

1) dokumentacja indywidualna - odnosząca się do poszczególnych pacjentów korzystających ze świadczeń zdrowotnych;

2) dokumentacja zbiorcza - odnosząca się do ogółu pacjentów lub określonych grup pacjentów korzystających ze świadczeń zdrowotnych.

Ponadto dokumentacja indywidualna obejmuje dokumentację indywidualną wewnętrzną, przeznaczoną na potrzeby podmiotu udzielającego świadczeń zdrowotnych, oraz dokumentację indywidualną zewnętrzną, przeznaczoną na potrzeby pacjenta korzystającego ze świadczeń zdrowotnych udzielanych przez podmiot. Dokumentacja indywidualna wewnętrzna obejmuje w szczególności historię zdrowia i choroby, historię choroby, kartę noworodka, kartę indywidualnej opieki pielęgniarskiej, kartę indywidualnej opieki prowadzonej przez położną, kartę wizyty patronażowej, kartę wywiadu środowiskowo-rodzinnego. Z kolei dokumentację indywidualną zewnętrzną stanowi skierowanie do szpitala lub innego podmiotu, skierowanie na badania diagnostyczne lub konsultację, zaświadczenie, orzeczenie, opinia lekarska, karta przebiegu ciąży, karta informacyjna z leczenia szpitalnego. Szczegółowe elementy wchodzące w skład dokumentacji indywidualnej, w zależności od podmiotu, jaki udziela świadczenia zdrowotnego, regulują dalsze przepisy rozporządzenia ${ }^{16}$. Jednakże odnosząc się do najczęściej podejmowanych

16 Dokonując analizy tychże przepisów, możemy przykładowo ustalić, jakiego rodzaju znieczulenie zostało podane pacjentowi, jakie były zlecenia lekarskie, wyniki 
w ramach prowadzonych postępowań sytuacji, należy odnieść się do istotnych regulacji dotyczących poszczególnych placówek świadczących opiekę zdrowotną.

I tak, podmiot leczniczy prowadzący szpital jest zobowiązany sporządzić i prowadzić:

1. dokumentację indywidualną wewnętrzną w formie historii choroby lub karty noworodka;

2. dokumentację zbiorczą wewnętrzną w formie:

a) księgi głównej przyjęć i wypisów,

b) księgi odmów przyjęć i porad ambulatoryjnych udzielanych w izbie przyjęć,

c) listy oczekujących na udzielenie świadczenia zdrowotnego finansowanego ze świadczeń zdrowotnych,

d) księgi chorych oddziału,

e) księgi raportów lekarskich,

f) księgi raportów pielęgniarskich,

g) księgi zabiegów,

h) księgi bloku operacyjnego albo sali operacyjnej,

i) księgi bloku porodowego albo sali porodowej,

j) księgi noworodków,

k) księgi pracowni diagnostycznej;

3. dokumentację indywidualną zewnętrzną $\mathrm{w}$ formie karty informacyjnej z leczenia szpitalnego, skierowania lub zlecenia na świadczenia

poszczególnych badań diagnostycznych bądź konsultacji, datę odmowy przyjęcia pacjenta do szpitala (ze wskazaniem roku, miesiąca, dnia oraz godziny i minuty w systemie 24 godzinnym), jak również adnotację o braku zgody pacjenta na pobyt w szpitalu potwierdzoną jego własnoręcznym podpisem albo podpisem jego przedstawiciela ustawowego. Oczywiście, wskazana tutaj przykłady stanowią jedynie wybiórczo wybrane elementy, nie zmienia to jednak faktu, że spektrum możliwych do uzyskania informacji wynikających z prawidłowo prowadzonej dokumentacji medycznej jest znaczne. Ograniczenie się wyłącznie do dokumentacji indywidualnej może nie odzwierciedlać w konkretnym stanie faktycznym wszystkich okoliczności, a tym samym obarczać postępowanie błędem braku. Na marginesie należy tylko zauważyć, że powołując biegłego celem wydania opinii,należy zalecić, aby biegły(li) odniósł się do kwestii, czy dostarczana do badań dokumentacja jest kompletna, czy też należy ją uzupełnić. 
zdrowotne realizowane poza szpitalem oraz dokumentacji dla celów określonych w odrębnych przepisach;

4. dokumentację zbiorczą zewnętrzną składającą się z dokumentacji prowadzonej dla celów określonych w odrębnych przepisach ${ }^{17}$.

Powyższa regulacja expressis verbis wskazuje na obowiązki szpitali w zakresie prowadzenia dokumentacji medycznej, jednakże nie rozwiązuje problemów związanych z przypadkami, w których świadczenia zdrowotne udzielane są $\mathrm{w}$ ramach prywatnej praktyki lekarskiej. Zgodnie z $\$ 57$ lekarz udzielający świadczeń zdrowotnych w ramach praktyki zawodowej jest zobowiązany do prowadzenia dokumentacji indywidualnej, która obejmuje dokumentację wewnętrzną $\mathrm{w}$ formie historii zdrowia i choroby lub karty noworodka, karty obserwacji przebiegu porodu, a także dokumentację zewnętrzną w formie skierowania do szpitala lub innego podmiotu, skierowania na badania diagnostyczne lub konsultacje, karty przebiegu ciąży, zaświadczenia, orzeczenia lub opinii lekarskiej.

\section{ZASADY PROWADZENIA DOKUMENTACJI MEDYCZNEJ}

Sposób prowadzenia dokumentacji medycznej, zgodnie z tym, co zostało już powiedziane, został w sposób bardzo szczegółowy unormowany w rozporządzeniu Ministra Zdrowia z dnia 21 grudnia $2010 \mathrm{r}$. w sprawie rodzajów i zakresu dokumentacji medycznej oraz sposobu jej przetwarzania. W oparciu o analizę w/w przepisów można wskazać co najmniej kilka zasad odnoszących się do sposobu prowadzenia dokumentacji medycznej, które mają na celu zapewnienie jej czytelności oraz rzetelności. W szczególności należy wskazać takie zasady, jak:

- zasada pisemności

- zasada dublowania informacji

- zasada chronologii dokonywanych wpisów

17 Szerzej nt. podziałów dokumentacji por. U. Drozdowska, [w:] U. Drozdowska, E. Kowalewska-Borys, A. Bieliński, W. Wojtal, Dokumentacja medyczna, red. U. Drozdowska, Warszawa 2012, s. 45-51. 
- zasada nieusuwalności wpisów

- zasada oznaczenia wpisów ${ }^{18}$.

Zasada pisemności została wyrażona expressis verbis w $\$ 1$ rozporządzania, zgodnie z którym dokumentacja medyczna jest prowadzona w postaci elektronicznej lub w postaci papierowej. Tym samym, wszelkie zdarzania o istotnym znaczeniu dla pacjenta, i związane ze świadczeniem mu opieki medycznej muszą znaleźć swoje odzwierciedlenie w prowadzonej dokumentacji medycznej. W istocie nie jest tutaj możliwe żadne odstępstwo od powyższej zasady, a w szczególności pomijanie wpisów $\mathrm{z}$ uwagi na werbalne informowanie pacjenta bądź członków personelu medycznego o świadczeniach zdrowotnych. Postępowanie takie nie tylko mogłoby wpłynąć na rzetelność prowadzonej dokumentacji, ale także narażać pacjenta na uszczerbek na zdrowiu bądź nawet utratę życia. Ponadto zawarte w formie pisemnej informacje dają obraz prowadzonego procesu leczenia, podejmowanych czynności czy wykonywanych zabiegów, które to z kolei stanowią podstawę do następczego stwierdzenia, czy proces leczenia odbywał się w sposób prawidłowy, zgodny z zasadami sztuki i wiedzy lekarskiej.

Zasada dublowania informacji pomimo braku jej literalnego wskazania w rozporządzeniu wynika ze jego szczegółowych uregulowań. Polega ona na powielaniu wpisów dokonywanych w dokumentacji medycznej w poszczególnych jej rodzajach. Tym samym analogiczne adnotacje możemy znaleźć w dokumentacji indywidualnej pacjenta, ale także np. w dokumentacji zbiorowej. Powyższe jest o tyle istotne z punktu widzenia postępowania karnego, iż w przypadku nierzetelnego prowadzenia dokumentacji bądź próby dokonywania w niej wpisów sprzecznych ze stanem rzeczywistym, konieczne jest zmienienie nie tylko jednego dokumentu, ale dokonanie stosownej wzmianki w kilku miejscach ${ }^{19}$.

\footnotetext{
18 W kwestii zasad por. także G. TARwański, R. MĄDro, Rola..., s. 25 -27.

19 Tytułem przykładu należy wskazać, że opis dotyczący procesu leczniczego znajduje się $\mathrm{w}$ dokumentacji indywidualnej pacjenta ( $\$ 10$ ust. 1 pkt 5 rozporządzenia), ale także w księdze głównej przyjęć i wypisów ( $\$ 26$ pkt 8 rozporządzenia) czy w księdze zabiegów ( $\$ 32$ pkt 6), bądź w księdze bloku operacyjnego ( $\$ 33$ pkt 10). Tym samym wprowadzanie zmiany wyłącznie w dokumentacji indywidualnej spowoduje jej sprzeczność z pozostałymi wpisami dokumentacji medycznej sensu largo.
} 
Zasada chronologii dokonywanych wpisów wynika wprost z $\$ 4$ ust. 1 i $\$ 5$ rozporządzenia. Zgodnie z powyższymi przepisami wpisu w dokumentacji dokonuje się niezwłocznie po udzieleniu świadczenia zdrowotnego, w sposób czytelny i w porządku chronologicznym. Ponadto strony $\mathrm{w}$ dokumentacji prowadzonej $\mathrm{w}$ formie papierowej są ponumerowane i stanowią chronologicznie uporządkowaną całość. W przypadku sporządzenia wydruku z dokumentacji prowadzonej w postaci elektronicznej, strony wydruku są numerowane. Regulacja taka ma przede wszystkim na celu racjonalne i uporządkowane prowadzenie dokumentacji medycznej, które pozwoli na czytelne zapoznanie się nie tylko $\mathrm{z}$ historią choroby danego pacjenta, ale także ze zlecanymi i wykonywanymi świadczeniami medycznymi. Z punktu widzenia odpowiedzialności karnej istotne może się okazać sprawdzenie, czy konkretny wpis nie został naniesiony w późniejszym terminie, a tym samym, czy nie zachodzi podejrzenie, że obrazuje on stan, który nie zaistniał.

Zasada nieusuwalności wpisów została określona w $\$ 4$ ust. 3 rozporządzenia, zgodnie $\mathrm{z}$ którym wpis dokonany $\mathrm{w}$ dokumentacji nie może być $\mathrm{z}$ niej usunięty, a jeżeli został dokonany błędnie, zamieszcza się przy nim adnotację o przyczynie błędu oraz datę i oznaczenie osoby dokonującej adnotacji.

Ostatnią zasadą, o której należy wspomnieć, jest kwestia oznaczenia wpisów dokonywanych w dokumentacji medycznej, zarówno w odniesieniu do pacjenta, którego dotyczy ( $\$ 6$ rozporządzenia), jak również w odniesieniu do lekarza. Zgodnie z $\$ 4$ ust. 2 każdy wpis w dokumentacji opatruje się oznaczeniem osoby dokonującej wpisu. Tym samym, każda naniesiona wzmianka w dokumentacji musi zostać „podpisana” przez autora, który jej dokonał. Dzięki powyższemu dokumentacja medyczna nie tylko staje się bardziej czytelna, ale przede wszystkim można ustalić, kto i kiedy dokonał wpisu, a w następstwie zbadać merytoryczną treść danego wpisu w kontekście odpowiedzialności tej osoby. 


\section{DokUmentaCja MEDYCZna JaKo DOWÓD W POSTĘPOWANIU KARNYM}

Doniosłość dokumentacji medycznej dla prowadzonego postępowania karnego, zgodnie z tym, co zostało powiedziane wcześniej, nie budzi żadnych wątpliwości. Jak trafnie pisze M. Filar, „Takie dokumenty, jak np. karty choroby, odpowiednie wpisy uczynione w księdze przyjęć, a zwłaszcza różnego rodzaju regulaminy szpitalne czy oddziałowe itp., mogą mieć podstawowe znaczenie m.in. w płaszczyźnie ustalenia udzielenia lub nieudzielenia pacjentowi określonego świadczenia zdrowotnego, personalnych obowiązków i zakresu kompetencji poszczególnych lekarzy"20. Jednakże powstaje pytanie o możliwości uzyskania wspomnianej dokumentacji przez organy wymiaru sprawiedliwości, zwłaszcza że zgodnie z art. 40 ustawy o zawodzie lekarza i lekarza dentysty lekarz ma obowiązek zachowania w tajemnicy informacji związanych z pacjentem, a uzyskanych w związku z wykonywaniem zawodu. Niewątpliwie dokumentacja medyczna stanowi zbiór dokumentów zawierających informacje na temat pacjenta i wytworzonych w trakcie świadczenia usług medycznych wobec pacjenta. Z kolei, zgodnie z art. 26 ustawy o prawach pacjenta i Rzeczniku Praw Pacjenta, podmiot udzielający świadczeń zdrowotnych udostępnia dokumentację medyczną pacjentowi lub jego przedstawicielowi ustawowemu, bądź osobie upoważnionej przez pacjenta. Ponadto Podmiot udzielający świadczeń zdrowotnych udostępnia dokumentację medyczną również „(... 3) ministrowi właściwemu do spraw zdrowia, sądom, w tym sądom dyscyplinarnym, prokuraturom, lekarzom sądowym i rzecznikom odpowiedzialności zawodowej, w związku z prowadzonym postępowaniem.” Do powyższej kwestii odnosi się expressis verbis art. 226 k.p.k., zgodnie z którym w kwestii wykorzystania dokumentów zawierających informacje niejawne lub tajemnicę zawodową jako dowodów w postępowaniu karnym stosuje się odpowiednio zakazy i ograniczenia określone w art. 178-181. Jednakże w postępowaniu przygotowawczym

20 M. Filar, [w:] M. Filar, S. Krześ, E. MarszaŁKowska-Krześ, P. Zaborowski, Odpowiedzialność lekarzy i zakładów opieki zdrowotnej, Warszawa 2004, s. 259. 
o wykorzystaniu jako dowodów dokumentów zawierających tajemnicę lekarską decyduje prokurator. Tym samym, na etapie postępowania przygotowawczego, to prokurator podejmuje decyzję o wykorzystaniu jako dowodu tej dokumentacji, przy czym ustawa nie konkretyzuje formy takiej decyzji. Wydaje się zasadnym przyjęcie, że samo uzyskanie dokumentacji może nastąpić na skutek wydania postanowienia o żądaniu wydania rzeczy bądź postanowienia o przeszukaniu. Z kolei wykorzystanie dokumentacji może nastąpić bez wydania jakiejkolwiek decyzji w tym zakresie, chyba że dokumentacja jest uzyskiwana w oryginale i w takiej formie przekazywana do sądu wraz z aktem oskarżenia ${ }^{21}$. W takiej sytuacji niewątpliwie zachodzi konieczność wydania postanowienia w przedmiocie dowodów rzeczowych. Jeżeli natomiast prokurator, po uzyskaniu dokumentacji, zlecił sporządzenie jej odpisów i zwrot oryginałów, postanowienie w przedmiocie uznania za dowód rzeczowy staje się zbędne. Oczywiście należy podkreślić, że sposób sformułowania treści postanowienia dotyczącego wydania dokumentacji winien uwzględniać konkretne okoliczności sprawy, w szczególności rodzaj żądanej dokumentacji oraz przyjętych hipotez dotyczących zdarzenia objętego postępowaniem ${ }^{22}$. Ponadto, organ prowadzący postępowanie winien wskazać postać, w jakiej ta dokumentacja ma zostać mu przekazana - czy ma to być tradycyjna forma papierowa, czy też ma ona zostać udostępniona w drodze elektronicznej. Zgodnie z art. 27 ustawy o prawach pacjenta i Rzeczniku Praw Pacjenta dokumentacja medyczna jest udostępniana:

1) do wglądu, w tym także do baz danych w zakresie ochrony zdrowia, w siedzibie podmiotu udzielającego świadczeń zdrowotnych;

2) poprzez sporządzenie jej wyciągów, odpisów lub kopii;

${ }^{21}$ Z praktycznego punktu widzenia rozwiązaniem bardziej zasadnym wydaje się uzyskanie oryginałów dokumentacji, a następnie zlecenie sporządzenia z nich odpisów z uwagi na podniesienie ewentualnego zarzutu niezgodności odpisu z oryginałami, jak również z przyczyn związanych z kosztami postępowania.

22 W zależności od stanu faktycznego, wystarczająca do ustalenia przebiegu zdarzenia może się okazać sama dokumentacja indywidualna pacjenta. W przypadkach jednak bardziej złożonych może się okazać konieczne uzyskanie również dokumentacji zbiorczej, w części lub w całości dotyczącej przebiegu leczenia pacjenta. 
3) poprzez wydania oryginału za pokwitowaniem odbioru i z zastrzeżeniem zwrotu po wykorzystaniu, jeżeli uprawniony organ lub podmiot żąda udostępnienia oryginałów tej dokumentacji.

Z kolei, jak wynika $\mathrm{z} \$ 83$ rozporządzenia udostępnienie dokumentacji prowadzonej w postaci elektronicznej następuje przez:

1) przekazanie informatycznego nośnika danych $\mathrm{z}$ zapisaną dokumentacją;

2) dokonanie elektronicznej transmisji dokumentacji;

3) przekazanie papierowych wydruków - na żądanie uprawnionych podmiotów lub organów. W przypadku udostępniania papierowych wydruków dokumentacji musi ona zostać potwierdzona, przez dany podmiot za zgodność z postacią elektroniczną. Dodatkowo na podmiocie zobowiązanym do udostępnienia dokumentacji medycznej spoczywa obowiązek pozostawienia kopii lub pełnego odpisu wydanej dokumentacji do własnej dyspozycji ${ }^{23}$.

\section{Podsumowanie}

Rola i funkcje dokumentacji medycznej w postępowaniach karnych, w szczególności dotyczących szeroko rozumianej problematyki medycznej, są nie do przecenienia. Z jednej strony stanowi ona lub przynajmniej powinna stanowić odzwierciedlenie zdarzeń związanych z przebiegiem leczenia osoby korzystającej ze świadczeń medycznych, z drugiej zaś może stanowić samoistny przedmiot czynu zabronionego. Poczynienie prawidłowych ustaleń dotyczących konkretnego stanu faktycznego jest związane nie tylko z uzyskaniem dokumentacji medycznej, ale również z koniecznością zapoznania się z poszczególnymi dokumentami i dokonaniem ich analizy pod kątem rzetelności oraz prawidłowości sporządzania. Ponadto, jak wskazuje praktyka, czyny zabronione związane bezpośrednio z samą dokumentacją są marginalizowane i praktycznie

23 Na marginesie należy zauważyć, że od dnia 1 sierpnia 2017 r. dokumentacja medyczna będzie prowadzona już wyłącznie w formie elektronicznej, co z jednej strony będzie stanowiło zabezpieczenie praw pacjenta, z drugiej zaś ograniczy możliwość jej uzyskania do tej właśnie formy. 
pozostawiane bez żadnej analizy. W tym zakresie należy jeszcze raz zgłosić postulat, aby w postanowieniach o powołaniu biegłego zwracać uwagę w szczególności, czy uzyskana dokumentacja jest kompletna, czy też konieczne jest poczynienie dalszych ustaleń w tym zakresie. W drugiej kolejności, niezależnie od oceny merytorycznej danego stanu faktycznego, zasadne jest odniesienie się przez biegłego do sposobu prowadzenia dokumentacji, prawidłowości wpisów etc. Jeżeli bowiem nawet w konkretnej sprawie nie będzie to miało znaczenia dla rozstrzygnięcia postępowania karnego, to $\mathrm{w}$ dalszej perspektywie może się okazać nad wyraz pożądane z punktu widzenia ochrony zdrowia samego pacjenta i wykształcenia prawidłowiej praktyki.

\section{Medical Records in Criminal Proceedings}

\section{Summary}

The subject of this article is the issue of medical records in criminal proceedings. First the author discusses the main problems connected with medical records in matters relating to criminal law. He then embarks on a definition of medical records and their types from the point of view of criminal law, the ways in which they are obtained, and the principles governing the collection and keeping of documents of this kind. The author's aim is not only to emphasise the relevance of medical records for criminal proceedings, but also to draw attention to their specific nature, and hence to their complexity and the potential they offer the judicature to obtain evidence if they are properly collected and kept.

Słowa kluczowe: dokumentacja medyczna, rodzaje dokumentacji medycznej, definicja dokumentacji medycznej, procedura karna, dowód przestępstwa.

Keywords: medical records, types of medical records, definition of medical records, criminal proceedings, evidence of crime.

\section{Literatura:}

Bielasińki J., Dokumentacja medyczna jawna dla pacjenta, «Jurysta» 11/2001 
Bogdan G., Ćwiąkalski Z., Kardas P., Majewski J., Raglewski J., SzewCZyK M., Wróbel W., A. Zoll, Kodeks karny. Część ogólna. Komentarz, I: Komentarz do art. 1-116 k.k., red. A. ZoLl, Zakamycze 2004

Dokumentacja medyczna, red. T. Banaś, T. Filarski, M. Mikos, P. РrochoPIEŃ, Warszawa ABC 2012

Drozdowska U., Dzienis P., Rozwadowska E., ZaŁuski W., Fiutak A., Leksykon prawa medycznego, red. A. GóRsKI, Warszawa 2012

Drozdowska U., Kowalewska-Borys E., Bieliński A., Wojtal W., Dokumentacja medyczna, red. U. DrozDowska, Warszawa 2012

Filar M., Krześ S., Marsza€kowska-Krześ E., Zaborowski P., Odpowiedzialność lekarzy i zakładów opieki zdrowotnej, Warszawa 2004

Fiutak A., Prawo w medycynie, Warszawa 2011

Kordel K., Prowadzenie dokumentacji medycznej - implikacje dowodowe, «Prawo i Medycyna» 3/2006

Kubiak R., Prawo medyczne, Warszawa 2010

LEGIEŃ M., Kryminalistyczna ocena wiarygodności dokumentacji medycznej w opiniowaniu sadowo-lekarskim, «Prokuratura i Prawo»10/1999

Liszewska A., Odpowiedzialność karna lekarza za bład w sztuce lekarskiej, Zakamycze 1998

Rutкоwsкi S., Wybrane zagadnienia z zakresu odpowiedzialności karnej lekarza, «Prokuratura i Prawo» 9/1999

Teresiński G., Mądro R., Rola dokumentacji medycznej w opiniowaniu sqdowo-lekarskim, «Prokuratura i Prawo»11/2002

Wolı́́sкa M., Odpowiedzialność karna lekarza za bład w sztuce lekarskiej, «Prokuratura i Prawo» 5/2013. 